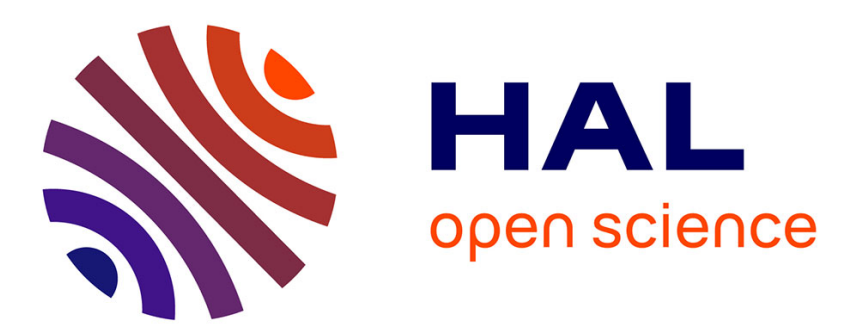

\title{
Endless Borders: Detaining Palestinians and Managing their Movements in the Occupied Territories
}

\author{
Stephanie Latte Abdallah
}

\section{To cite this version:}

Stephanie Latte Abdallah. Endless Borders: Detaining Palestinians and Managing their Movements in the Occupied Territories. Daniel Meier. In-Between Border Spaces in the Levant, Routledge, pp.100-121, 2021, 9780367632359. hal-03470082

\section{HAL Id: hal-03470082 \\ https://hal-sciencespo.archives-ouvertes.fr/hal-03470082}

Submitted on 8 Dec 2021

HAL is a multi-disciplinary open access archive for the deposit and dissemination of scientific research documents, whether they are published or not. The documents may come from teaching and research institutions in France or abroad, or from public or private research centers.
L'archive ouverte pluridisciplinaire HAL, est destinée au dépôt et à la diffusion de documents scientifiques de niveau recherche, publiés ou non, émanant des établissements d'enseignement et de recherche français ou étrangers, des laboratoires publics ou privés. 


\section{To quote this paper:}

Stéphanie Latte Abdallah, « Endless Borders: Detaining Palestinians and Managing their Movements in the Occupied Territories », in Daniel Meier (ed.), In-Between Border Spaces in the Levant, Routledge, 2021, p. 100-121.

Stéphanie Latte Abdallah (CNRS/CERI-SciencesPo, Paris)

\section{Endless Borders: Detaining Palestinians and Managing their Movements in the Occupied Territories ${ }^{1}$}

Following the second Intifada (2000-2004), the Israeli authorities implemented new territorial, military and institutional control mechanisms within the Occupied Palestinian Territories (OPT) despite the illusionary territorial separation created by the on-going erection of the Wallbetween the West Bank and Israel since 2002 (Latte Abdallah, Parizot 2011, 2015, 2017). Thecontrol mechanisms of the occupation have been redesigned for a territory envisaged as discontinuous, in total contradiction with border logic, i.e. with the classical line-borders of themodern nationstate and those considered by international law.

The Israeli authorities have implemented two main types of control mechanisms: on the one hand, territorial devices have been deployed on the other side of the Wall such as fixed or flying checkpoints and different types of obstacles (watchtowers, earth mounds, trenches, concrete blocks etc.); on the other hand, non-territorial structuring and sustainable mechanisms have been enforced, such as the permit system gradually implemented since 1991 and the renewal of mass imprisonment policies -inaugurated during the $1^{\text {st }}$ Intifada- that turned imprisonment into a population management technique.

\footnotetext{
${ }^{1}$ This research has benefited from a H2020 EU funding (Magyc Project).
} 
Hence, the Israeli authorities reinforced their presence on both sides of the Wall. They deployed control mechanisms in the heart of the Palestinian enclaves. A process of debordering through expansion notably through the ongoing multiplication of Jewish settlements was gradually implemented (Parsons and Salter 2008). The Israeli army formed what it called 'land cells' (Dayan 2009): a system of potential opening and closing of enclaves that was set up to close Palestinian villages and towns on various security grounds. In this way, it sought to avoid friction between two populations likely to enter into confrontation, the settlers and the Palestinians. These spatial redeployments have isolated Palestinian spaces from each other, allowed their potential closure whilst managing traffic between them and developed distinct circulation routes. Different mobility regimes were attributed to Israelis and Palestinians, but also among Palestinians (Petti 2008, Latte Abdallah and Parizot 2011, 2015). The projection of control within the Occupied Territories, and since the disengagement of Israel from the Gaza strip in 2005 mainly within the West Bank, has thickened and multiplied the border. In a sense, the entire West Bank has now become an in-between border space.

Previous works have discussed the increasing carceralisation of the West Bank and the Gaza Strip through three main devices: prisons, checkpoints and walls (Bornstein 2008). The OPT have thus been described as a "carceral society" (Bornstein 2008) or a "carceral archipelago" (Gregory 2004, Parsons 2010). Others have tackled the impact of territorial control devices on the fragmentation of space and movements, on the mobility and multiplication of the border (Weizman 2007) and the role of bureaucracy, of documentation and lately of the permit system (Parsons and Salter 2008, Berda 2017) in the "matrix of control" in the OPT (Halper 2000). Though, none of them have focused on military justice practices and mass imprisonment policies per se in such a context of multi scalar confinements and production of boundaries.

Since the $2^{\text {nd }}$ Intifada, mass arrests and incarcerations for political reasons have indeed reactivated what I called a Prison Web, which is both a reality and a virtuality, i.e. the suspended legal possibility to arrest and detain a large number of people, men and women from the age of 12 (Latte Abdallah 2011, 2015). The Prison Web is a main control tool. Since 1967, different sources estimate that approximately $40 \%$ of the male population has been jailed. The prison experience is widely shared and marks personal and collective stories, be it the result of an active and lasting party activism, armed or violent action, occasional participation in demonstrations, uprisings, clashes, or of relatives or acquaintances' activism. Between 2006 and 2008, at the time of the repression of the second Intifada, about 8,000 Palestinians were detained. Arrests once more became massive since the renewed outburst of violence that started in autumn 2013 and became in October 2015 the 'Knife Intifada', termed by the Palestinians 
the 'Small Uprising (habbeh)'. According to the figures of the Israeli police, 17396 Palestinians from the West Bank and East Jerusalem were arrested in 2014. According to the Israeli NGO B'Tselem, there were 4787 'security prisoners' the 31 of August $2019^{2}$ (and 629 considered as 'criminals' for illegal residence in Israel) and 5000 in September 2019 according to the Palestinian NGO Addameer ${ }^{3}$. They are usually called prisoners of war (asra) or political prisoners by the Palestinians and depicted as security prisoners by the penitentiary administration, the Israel Prison Service (Shabas).

Hence, this paper aims to show how judiciary and prison practices per se applied to Palestinians residents of the OPT (mainly to West Bankers but also to Palestinian Jerusalemites and Gazans) are main control devices that are contributing to shape a bordering system ${ }^{4}$ anchored on a specific 'mobility regime' ${ }^{5}$ : how the prison system tied to military justice use arrests and detention to manage borders of the nation that are non-linear but have been multiplied, are partly dematerialized, mobile, "networked" (Popescu 2012) and became both individualized and endless.

First, I will show how the ethnicization of the judiciary and the prison system contributes to create a territory which functions as an in-between border space. Then, I will deal with the expansion of the grip of the Prison Web. It has created a diffuse and effective system of control which targets both the individuals and their networks and a massive data collection system on the Palestinian population and social and political life in the Palestinian enclaves. Through massive arrests, the intelligence services (the Shabak also called Shin Beth) gather information, recruit informers and collaborators and infiltrate the entire society. This data system is the basis of the biosocial profiling necessary for policing, risk and mobility management (Shamir 2005) within a territory considered as discontinuous and without line-borders. Then, I will demonstrate how punishment is linked to and organizes Palestinians' differential capacity of mobility even after their release from jail. This stratification is a main bordering factor. It has individualized the border: according to his profile, each one carries his own capacity of

\footnotetext{
${ }^{2}$ B'tselem takes into account all Palestinian detainees from the OPT (irrespective of whether they have been convicted or are detained the time of examination or trial or whether they are administrative detainees). Since August 2008, these statistics also include residents of East Jerusalem. These figures, however do not include Palestinian citizens of Israël, and common law prisoners. B'Tselem statistics are those provided by the Israeli Prison Service. See https://www.btselem.org/statistics/detainees_and prisoners.

${ }^{3}$ See http://addameer.org/statistics.

${ }^{4}$ Following Didier Bigo, I envisage borders from their functioning, i.e. as an articulation of networks of heterogeneous actors and flows of control operations which goal is to filter, channel and organize the movement of people and goods in a discontinuous territory (2010).

${ }^{5}$ By 'mobility regime' I mean all the institutions, regulations, infrastructures and practices that, since the 1990s, have allowed Israelis to regulate, channel and monitor the daily circulation of Palestinians between, in and from the West Bank, Israel, East Jerusalem and the Gaza Strip (Latte Abdallah and Parizot 2017).
} 
movement. Dispersed throughout the territory and within society, the border functions as a data network (Popescu 2012). Lastly, I will show how mass incarceration policies and this networked bordering system became relatively cost-effective by the offloading of some of its cost onto the Palestinians and the international community. The sustainability of main control devices such as military justice and the prison system has indeed been obtained through neoliberal reforms (outsourcing, privatization of services, etc.) and by the monetarization of the judiciary and the prison business it has created.

\section{The ethnicization of the judiciary and prison system: extra-territoriality and non-sovereignty}

\section{in an in-between border space}

A dual legal system (Hajjar 2005) has gradually been established according to ethno-national criteria which distinguish Israelis from Palestinians and sometimes Jews from Arabs. It contributes to create a territory which is, in practice and despite the provisions of international law, legally undetermined beyond the green line $^{6}$ and functions as an in-between border space. As researchers Ben Naftali, Gross and Michaeli have rightly pointed out, the lack of clearly defined territorial boundaries had as a corollary -if not as a goal- of erasing a whole set of distinctions, especially between occupation and non-occupation, annexation and nonannexation, temporary and indefinite, and thus between the rule and the exception (2009). This uncertainty has deprived the Palestinians in the territories, on the one hand of the protection of international law of occupation, and, on the other hand, of the rights of Israeli or Palestinian citizens to the benefit of a government by a series of regulations, military orders and procedures. This ethnicization of the judicial and prison systems is indeed grounded on two main disjunctions: firstly, between the territories and the legal competences of the Israeli military justice and Israeli and Palestinian civil justices; secondly, between the type of crimes and the competent jurisdiction that ultimately judges the case.

Indeed, military justice in the West Bank has no territorial jurisdiction but an ethno-national one. Settlers are not tried by military courts contrary to Palestinians, i.e. residents of the West Bank and the Gazans until the disengagement of Israel. Military courts do not judge either Palestinians from Jerusalem because of the annexation of the city by Israel following the 1967 war. In July 1967, a law was passed to give Israeli civil courts jurisdiction in the Occupied Palestinian Territories to try Israeli citizens exclusively (Hajjar 2005, Tsemel 1985). Moreover, military courts have extraterritorial jurisdiction: they can adjudicate security cases for other

\footnotetext{
${ }^{6}$ The 1949 Armistice line between Israel and Jordan which were the de facto borders of Israel till the 1967 war and the occupation of East Jerusalem and the West Bank that were under Jordanian control.
} 
Palestinians if the incrimination involves a Palestinian or an Israeli living in the occupied territories ${ }^{7}$. For them, it qualifies almost immediately the crime as a security crime. This ethnonational penal system is therefore not limited to the West Bank but sometimes applies to Palestinian Jerusalemites as well as to Palestinians citizens of Israel or residing abroad, or to other Arabs (Syrians of the Golan annexed in 1981, Jordanians, Lebanese, etc.). In addition, for Arabs, certain common law offenses can be qualified as 'security cases' if they are motivated by 'nationalism" .

Since the second Intifada (2000), an increasing number of Palestinian civil offenses have been tried by military justice. According to Israeli lawyer Leah Tsemel, for the Palestinians, they have gradually become the courts of the West Bank, thus heavily undermining the role of Palestinian civil justice and the sovereignty of the PA in the enclaves it controls. Israeli Military Courts are dealing with civil offenses and common law crimes notably as soon as an Israeli or Israeli state-owned or individual property are concerned ${ }^{9}$ such as trafficking including drugs and theft of Israeli cars, property offenses in the settlements or in Israel, land disputes and all traffic offenses committed in zones $\mathrm{C}$ and $\mathrm{B}^{10}$. Among civil offenses, arrests and trials for illegal presence in Israel have risen significantly in recent years because of the restrictive permit system. The grip of blacklisting, coupled with economic pressure on the West Bank, is pushing more men to work in the settlements in the West Bank and cross illegally to work in Israel ${ }^{11}$. Some others go to Jerusalem or to Israel for personal reasons without applying for a permit that is unlikely to be obtained.

The analysis of the charges between 2002 and 2006, i.e. during the $2^{\text {nd }}$ Intifada and its repression, shows that military courts tried a superior load of civil offenses compared to socalled 'security crimes'. Indeed, the report of the Israeli NGO Yesh Din states that securityrelated offenses ('Hostile Terrorist Activity' - fakhaï-Hebrew) concerned only 33 per cent of the indictments while civil offenses accounted for 67 per cent. And within security-related violations, only 4 per cent of the cases were homicide attempts and 1 per cent were intentional homicides. Traffic offenses alone accounted for 38 per cent of the offenses and the 'Illegal presence in Israel' category for 15 per cent (Yesh Din 2007). In 2007, the Military Courts Annual Report stated that 47 per cent of the indictments were for 'Hostile Terrorist Activity'

\footnotetext{
${ }^{7}$ Leah Tsemel, Israeli lawyer, Interview, Jerusalem, 29/04/2011.

${ }^{8}$ Israel Prison Service (Shabas), Ordonnance 04.05.00, 18/3/2014.

${ }^{9}$ Leah Tsemel, Interview, Jerusalem, 20/04/2011.

${ }^{10}$ And the non-payment of such traffic fines prevents from obtaining a permit to enter or cross Israël, including Jerusalem (Berda 2017).

${ }^{11}$ See Bontemps (2017) and Parizot (2017).
} 
(Machsom watch 2008). It dropped to $20 \%$ in 2017 whilst the indictments for traffic violations rose to $50 \%$ according to figures from the Military Court published by the Palestinian NGO Addameer $^{12}$.

The Oslo zoning between areas A, B and $\mathrm{C}^{13}$ and the superposition of jurisdictions seriously hamper the functioning of Palestinian civil justice in A and B zones and further increase the scope of intervention of Israeli military courts in the West Bank. On the one hand, many criminals and criminals prosecuted by the Palestinian justice find refuge in zone $\mathrm{C}$ (or even $\mathrm{B}$ ) where the Israeli forces do not systematically arrest them either for political reasons and/or due to a lack of coordination between Palestinian and Israeli forces. On the other hand, trials are difficult to conduct due to the procedures imposed on Palestinians for moving defendants or witnesses between zones. The movements of Palestinian forces between zones A or B are indeed strictly supervised. Because they have to cross zones $\mathrm{C}$ and use the main road network, they require security coordination between Palestinian and Israeli authorities. As a result, petty crime and other forms of trafficking have increased significantly in areas B and C, creating zones of lawlessness. Criminal networks are then instrumentalized by the Israeli authorities for intelligence purposes ${ }^{14}$. By arresting these offenders or criminals at their convenience and trying them in military courts, the Israeli intelligence services have many levers to obtain information. Finally, the Israel Prison Service (Shabas) definition and detainee classification system as 'security prisoners (A)' or 'common law prisoners (B)' also categorize along ethno-national grounds. Hence, very few Jewish Israelis have been considered security prisoners such as Ygal Amir, the murderer of Ytzak Rabin, and even then, their detention conditions are different from Palestinians security detainees. On the contrary, Palestinians, whatever citizenship and status (citizens of Israel, Jerusalemites, residents of the West Bank or the Gaza Strip) they hold, and Arabs (Syrians of the Golan, Lebanese, Jordanians, etc.) are much more likely to be considered as such. The classification as a security prisoner is not a legal provision ${ }^{15}$. It is an internal administrative decision of Shabas taken by the director of the establishment or by the head of the prison intelligence services after consultation with the police and Shin Beth. It is primarily

\footnotetext{
${ }^{12} \mathrm{http}$ ://www.addameer.org/publications/military-courts-occupied-palestinian-territory.

${ }^{13}$ In the A zones, where most of Palestinian cities are and count today for 18 per cent of the territory, Israel delegated to the Palestinian Authority (PA) civil and security control. In the B zones where the majority of the villages are (22 per cent of the territory), the PA is supposedly responsible for public order and the internal security of the Palestinians while Israel is in charge of external security. Lastly, zones $\mathrm{C}$ where most of the agricultural lands and the entire road network are located and amount to 60 per cent of the territory, remained under Israeli control.

${ }^{14}$ See Natsheh, Parizot, 2015 ; Parizot, 2017.

${ }^{15}$ Ordonnance 04.05 .00 , op. cit.
} 
intended to facilitate the management of prisons by isolating various types of prisoners. This classification determines in which prison and section the person is detained and serves his sentence. It entails specific rights in detention. The rights of security prisoners are indeed drastically restricted and are being re-evaluated according to changes in the political and security situation in Israel / Palestine ${ }^{16}$.

\section{The Prison Web: Indetermination, Networks and Data collection}

The Prison Web is a major system of control. It is mostly tied to the functioning of military justice, its characterization of crimes and its confession-based proof. Being both a reality and a possibility of being arrested and tried, this Prison Web participates in the creation of a space which is kept suspended and therefore indeterminate. A space where law and fact merge and everything becomes possible (Agamben, 1997).

Firstly, the Prison Web creates a diffuse system of control likely to affect all Palestinians on account of the family, social, local, professional or militant networks in which they are de facto inscribed by their ties, their places of living or their activities. Indeed, this judicial system operates out of the intelligence services. Together with the army or police, the Shin Beth arrests suspects. The latest is in charge of conducting the interrogations (takhqiq - [Arabic]) and decide upon the renewal of remand of custody before indictment. When a person is wanted (matlub Arabic), being linked to her by any of these networks may result in an arrest and interrogation of up to 90 days by the Shin Beth who is not required to disclose the reason for the arrest to lawyers. The intelligences services might invoke a security reason for keeping it in the 'secret file' that only the judge assesses. These network arrests are named by some lawyers 'the grocery list'. For instance, in order to incriminate the leaders of the popular resistance in the villages, the Israeli authorities use similar methods: they arrest a bunch of minors, preferably chosen among the most fragile psychologically, economically or education wise whom it is easier to put pressure on to have them accuse the activists ${ }^{17}$. Such ties and networks are used to control and are objectivized as potential threats.

In addition, such arrests may last and become imprisonment periods under the provisions of administrative detention which allow holding a person in detention for renewable six-month

\footnotetext{
${ }^{16}$ Let's briefly recall here a few points: for security prisoners, visits are limited to first-degree relatives and their number is limited to one every two weeks. They are imperatively made through a window and a phone. Inmates do not have access to the telephone except in the event of the death of a close relative. They cannot obtain exit permits during their sentence. They are more closely supervised and receive harsher punishments for breaching detention regulations. And they have almost no possibility of sentence adjustment or remission (Latte Abdallah 2011, 2014, 2015).

${ }^{17}$ Interview with a lawyer at Ofer Military Court, 27/10/2016.
} 
periods without charge. The charges are usually kept secret and at the discretion of the Shin Beth. It greatly expands the Prison Web and the temporal boundaries of the prison system. The purpose of this type of detention is indeed presented as a way of avoiding any 'future activity' that would threaten security (Cavanaugh, 2007).

Secondly, the predominant role of the Shin Beth continues throughout the judgment process and, in various ways, during the imprisonment period (notably as far as classification, management of the detainees and punitive measures are concerned). At the military court, a special evidence system is used: it is not primarily based on investigation and evidence discussed at trial but on confessions of the defendants or on statements and denunciations of third parties on their alleged activities - known in Hebrew as the Tamir practice. Interrogators therefore have to obtain such confessions at any price. Hence, since the beginning of the occupation and until 1999, physical and psychological violence - similar to torture - was regularly used during interrogations. Since the 1999 Supreme Court decision, heavy psychological pressures have replaced, in most cases only, physical and sexual abuse (Latte Abdallah 2011, 2013).

This system of confession-based proof appears particularly significant once pointed out that more than 97 per cent of cases never come to trial but are settled through a system of plea bargaining - safqa (Arabic) - between lawyers and judges (Hajjar, 2005; Yesh Din 2006). This procedure requires a confession of guilt from the defendant (Hajjar, 2005). Plea-bargaining is advantageous for the military legal authorities who settle cases faster by avoiding trials. Pleabargaining is not specific to Israeli military courts. Though its systematic use by military courts and the wider context of military justice and occupation in the West Bank have specific implications. Lawyers and families of detainees usually opt for plea-bargaining because it usually results in shorter sentences. In contrast, the refusal to negotiate results in heavier sentences and endless proceedings - during which the defendants are kept in detention. Senior lawyers initiate trials in few cases only, when for instance their clients are public figures who take the risk of the trial for political reasons. Though, some other detainees state they prefer plea-bargaining to trial for political reasons: this choice is then presented as a non-recognition of military justice (Hajjar, 2005).

Whatever the reasons for this choice, this procedure significantly extends the grip of the Prison Web. It increases, at a low cost, the number of imprisonments and convictions. Almost 100 per cent of defendants are convicted of part of the charges led against them while less than 1 per cent is acquitted (Machsom Watch 2008, Yesh Din 2007). More broadly, this proof system based on confessions and denunciations greatly strengthens the grip of the intelligence services 
over the Palestinian population. Hence, they benefit from a significant source of information and constitute files on the defendants, and members of their social and political networks. The courts are constantly trying to increase the use of safqa not only to save time and money but also to justify the involvement of the intelligence services in military courts, and to give such military justice national and international legitimacy. This confession-based proof and the practice of plea-bargaining provide some kind of justification to mass arrests and to the objectionable functioning of military justice to Israeli and international public opinion, through convictions for crimes that are recognized by their supposed perpetrators or by third parties but remain unproven.

As discussed above, the main bulk of indictments are related to civil offenses. In addition, among the 47 per cent that were security-related cases in 2007 (which dropped to 20 per cent in 2017), most of the people were not accused of 'terrorist acts' resulting in or attempting to bring about death but of simply belonging to or having activities inside an 'illegal organization'. Membership of an illegal organization is defined in vague, general terms and includes an entire spectrum of relations summed up in the expression 'having links' to an illegal organization irrespective of their nature. Moreover 'illegal organizations' include both organizations declared to be terrorists and others considered illegal. The list of illegal organizations has indeed gradually expanded to include more and more social and civil structures such as non-profit and NGOs...etc. Since the beginning of the occupation, none of these classified as illegal organizations' have been removed from the list. Hence, all Palestinian political parties, which were declared 'terrorist organizations' in 1986, are on the list including Fatah despite its role in the Oslo Accords and the fact that it constitutes the basis of the PA ${ }^{18}$. Moreover, the sense of time is blurred: such 'links' may indeed have been forged in the past at a time when the said organization has not yet been classified as illegal (Machsom Watch 2008). Although few people nowadays are arrested merely for belonging to Fatah, the option is still there. Hence, the Prison Web which may be defined as the possibility of imprisoning, i.e. a prison reality and a virtuality, is activated according to the situation and the needs of the intelligence services.

The arrest of members of Fatah were so massive during the second Intifada (2000-2006) that they still form the large majority of detainees. Since 2009, in addition to the members of Hamas and the Popular Front for the Liberation of Palestine, activists engaged in the peaceful protests of the Popular Resistance Committees in the villages contesting the construction of the Wall and the settlers land grab (in Nai'lin, Bei'lin, Nabi Saleh, etc.) are frequently indicted (Addameer

\footnotetext{
${ }^{18}$ For more details, see Latte Abdallah 2011, 2015.
} 
2013). Imprisonment for belonging to Hamas and organizations considered to be terrorists have fluctuated because the Palestinian Authority security forces do arrest them pre-emptively, as part of the security cooperation agreements with Israel that were reformulated under the auspices of the United States in 2007. Other forms of activism and expression have recently been targeted with the sharp rise of incriminations for activities or incentives on social networks, the arrest of journalists, and activists and leaders of the BDS movement (Boycott, Divestment and Sanctions) such as Omar al-Barghouti, one of its founders, in March 2017. In 2013 and 2014, according to the Israeli NGO Court Watch ${ }^{19}$, most of the defendants were young men - including many minors - charged for throwing stones. The regular follow-up of trials between 2014 and 2016 and interviews with lawyers at the military court in Ofer confirmed that only a tiny minority of cases classified as 'security' are homicides or attempted homicides.

In return, through these ongoing arrests, the intelligence services gather information, recruit collaborators, infiltrate the entire society ...etc. This Prison Web is one of the key systems of control because it is a main tool for massive data collection on the Palestinian population, not only about political stakes, ideas and activities but also about social life, the networks of relations and ties and daily life in Palestinian enclaves. Genealogies, individual and family histories are then used to locate wanted people, to put pressure on people under interrogation or negotiate specific services in exchange for instance for work, travel or circulation permits ${ }^{20}$. Indeed, the development of the permit system is also part of this same process of control of daily life on a massive scale and recruitment of thousands of informants to the Shin Beth (Berda 2017).

\section{Punishment and Mobility}

Penalties partly depend on the mobility capacity of the defendant and often determine his possibilities of movement once released from jail. It shows the role given to the penal and prison system in the management of flows, and thus in the management of the nation's borders.

The citizenship and residential status of Palestinians determine the convictions and length of sentences. Offenses of Palestinians with Israeli citizenship (Palestinians of 48) and Palestinians from Jerusalem are more frequently considered as 'security cases' than those of Jewish Israelis for similar crimes, as the 'nationalist' motivation of their actions can be invoked. Classified as

\footnotetext{
${ }^{19}$ Court Watch was established in 2005 by activists from the NGO Machsom Watch (formed in 2000 by a group of women to monitor soldiers' practices at checkpoints). More engaged yet, members of Court Watch attend military court hearings and reports on court practices.

${ }^{20}$ Interview with a former delegate of the International Committee of the Red Cross, Paris, 12/05/2009.
} 
'security prisoners', they share the same conditions of detention as the vast majority of Palestinians of the Occupied Territories and Arabs nationals of foreign countries. In addition, they are more heavily punished as enemies from within. For the State of Israel, as citizens (or, to a lesser extend as permanent residents - regarding Jerusalemites), they are in general excluded from political negotiations for their release and from prisoner exchange deals ${ }^{21}$. The mobility capacity that results from their citizenship or their resident status increases the sentences. Indeed, they receive harshest punishments because they can circulate freely in the Israeli - and Palestinian - spaces, and consequently develop broader networks and connections. FrenchPalestinian Salah Hamouri was sentenced to 8 years in prison by plea bargain for admitting being a member of the Popular Front for the Liberation of Palestine (PFLP), when hewas 22 years old ${ }^{22}$. According to his lawyer Leah Tsemel, he received such a heavy sentence because of his leadership and activism at the university while he is both Jerusalemite and French, and consequently has a high mobility capacity and international networks that increasehis influence. If the citizenship, status and mobility of 48 Palestinians and Jerusalemites give them greater 'dangerousness' when charged and convicted, they are less subject to administrative detention than residents of the Gaza Strip and the West Bank. The decision to detain administratively the inhabitants of the OPT requires a basic military order of the head of the army of the city or region concerned while the validation of the Minister of Defense is compulsory for Jerusalemites and the signature of the Prime Minister for Israeli citizens. However, as Israeli citizens, 48 Palestinians are not subject to deportation or travel bans as part or extension of their sentence, unlike the residents of the Gaza Strip, the West Bank or Jerusalem.

Since 1967, deportations have been widely used, after time spent in prison, as a condition of early release or as an alternative to prison sentences. With the introduction of the permit system, from the mid-1990s onwards, deportations have increased. This policy of forced exile or selfexile has forced migrations abroad and unprecedented internal exiles (Dayan 2009). These deportations may be temporary or indefinite.

Despite the efforts of Hamas negotiators to avoid the application of deportation measures to the first wave of Palestinian prisoners exchanged for Gilad Shalit in 2011, which included those serving perpetuities and long sentences, various categories were distinguished which shows

\footnotetext{
${ }^{21}$ This is why the release of 48 Jerusalemites and 7 - 48 Palestinians - at the end of 2011 was considered a success of Hamas in the Shalit deal. In October 2011, this agreement provided for the release of the soldier Gilad Shalit held since June 2006 by Hamas in the Gaza strip in exchange for the enlargement of 1027 Palestinian prisoners.

${ }^{22} \mathrm{He}$ was also accused of aiming at murdering the Shass leader Ovadia Yousef but he contested this charge. Denise et Hassan Hamouri, Interview, Ramallah, 30/10/2011.
} 
how citizenship, residence status and mobility capacity determine sentences and releases : out of these 477 freed prisoners, all Gazans (132) were able to return to their homes in the Gazacontrolled territorial cell, with the exception of one. Of the 300 inmates from the West Bank, $22 \%$ returned to the West Bank unconditionally and $16 \%$ were subject to mobility restrictions varying according to locations and time (referred to as "security arrangements"). The vast majority of west bankers were exiled (66\%): half of them (52\%) had the choice between moving abroad or to Gaza for an indefinite period, and $6 \%$ had the same alternative but for a limited period of 3 years. Finally, 8\% were exiled abroad to Turkey, Jordan and Qatar. Among the 45 Jerusalemites, an even higher proportion was exiled (69\%) while the inhabitants and the activities in the city are particularly watched and sanctioned when the policies conducted since the second intifada tend to push its Arab residents out. 29\% of the Jerusalemites had to leave the country, $40 \%$ were able to choose to live in Gaza or abroad for 3 years. $20 \%$ returned home, and $11 \%$ were assigned circulation perimeters ("security arrangements"). Finally, only 7 Palestinians from 48 were released, but thanks to their Israeli citizenship they almost all returned home $(6)^{23}$.

Added to the major role of the Shin Beth during investigation and trials that was described previously, the intelligence services have a significant impact on the penalties and on the mobility of ex-detainees once released from jail. Their relatives are also likely to be hindered in their movements. Indeed, it has become the central agency that shaped policy to manage the Palestinian population, mainly through its classification on a sliding scale of risks and into categories of security threats according to a template supplemented by changing criteria that consider age, gender, geographic area, family, place of residence, political affiliation, economic status, intelligence information, type of movement required and duration, the person's affiliation with Israel, the time of the day...etc. (Berda 2017). Besides the stratification and mobility ranking due to their citizenship status and places of living (the West Bank, the Gaza Strip or Jerusalem ${ }^{24}$ ), Palestinians have different mobility capacities according to their biosocial profiles that further split the movements. Hence, the permit system ballooned after the second Intifada into a system that included multiple criteria expanding to more than 100 types of circulation permits (Abu Zahra and Kay 2012, Berda 2017). Separate permits with defined frequency and duration are issued to travel abroad, to go to Jerusalem or Israel for medical

\footnotetext{
${ }^{23}$ List of security prisoners, 15.10.2011, Israel Prison Service.

${ }^{24}$ Palestinian-citizens of Israel and Palestinians of Jerusalem - considered as permanent residents - have distinct statuses but can move throughout the Israeli-Palestinian space. Palestinians in the West Bank must apply for a permit to leave the territory while being able to travel abroad via Jordan only. Gazans are confined in the Gaza Strip, of which they can only very rarely go out with an Israeli permit or through Egypt.
} 
consultations, for work, to pray at al-Aqsa Mosque, to visit a relative in jail, to go to the Gaza Strip ...etc.

The enhanced hold of security and intelligence services on arrests, imprisonment and mobility management has increased the use of blacklisting practice by Israeli intelligence services: if only a few thousand had been blacklisted before 2000, about 260,000 were blacklisted between 2000 and 2005 to the point where they could no longer obtain permits to enter Jerusalem or Israel or to leave the West Bank or the Gaza Strip (Braverman 2010, Machsom Watch 2007). As a result, in 2007, about 20 per cent of the male population of the WB between the ages 1655 was classified as security threats (Berda 2017). Anyone involved in court proceedings is classified as a 'criminal security threat' and cannot obtain a permit to enter Israel (Berda 2017). Former detainees are thus immediately 'blacklisted'.

Family members of detainees or ex-detainees, politicized people, especially young men, are often targeted by these measures and face difficulties in obtaining permits to leave the country, to enter Jerusalem or Israel, to travel to the Gaza Strip or to visit a relative in detention. From the beginning of the 2000s, all the prisons of the Occupied Territories, which were military prisons, were relocated within the pre-1967 borders of Israel ${ }^{25}$ and institutionally integrated into the Israeli civil prison system ${ }^{26}$. Since, a permit is compulsory to visit first-degree parents in prison (parents, children, brothers and sisters, the only ones who are allowed to visit an inmate). Special 'security permits' have been created and are used to come to the visit in Israeli jails. Primarily based on gendered and age-related general criteria, they are automatically required for men between 16 and 35 years old. But they can only be requested on a case-by-case basis, are valid for one visit and are obtainable only through a lengthy and complicated bureaucratic process.

Moreover, at the time of their release, as mentioned above, some prisoners are being ordered internal travel restrictions and mobility perimeters according to the time of the day, in addition to prohibitions to leave the territory. These travel bans are frequently renewed without any specific reason by the laconic formula: represents 'a threat to the security of the area'. This practice is not new but it gained a significant impact within the bordering system implemented after the second Intifada and the end of the Oslo process. In the early 2000s, when he was ultimately released from jail, Oussama Barham was given a map of the West Bank with different colors: in purple were the places where he was always forbidden to go, in green those

\footnotetext{
25 Except the Ofer prison located in zone $\mathrm{C}$ in the West Bank.

${ }^{26}$ See Latte Abdallah 2011, 2015.
} 
where he was not supposed to go after midnight, and in blue those that were allowed any time. These restrictions of movement were added to an on-going travel ban that applied since his first prison term in 1982.

Taken together, all these criteria and their applications constitute main bordering factors that have individualized the border: according to his profile, each one carries his own capacity of movement. Dispersed throughout the territory and within society, the border functions as a data network and has become what Popescu calls a networked-border (2012).

\section{Neoliberal reforms and the outsourcing of the Prison Web}

The integration of military prisons under the authority of the Prison Service has been justified on grounds of professionalism and on humanitarian grounds (improvement in the conditions of detention including modernization, renovation and construction of prisons). But other considerations were at work. Firstly, the intelligence services played a key part in this integration process. They enhanced their role in managing detainees since as officio members of the board of Shabas, they participate in decisions and greatly inspired the new political prison management of Palestinian prisoners ${ }^{27}$.

Secondly, it was motivated by economic viability and the possibility to reduce the cost of mass incarceration policies through neoliberal reforms. On the one hand, costs have been reduced by using more sophisticated technology, Human Resource Management and privatization of certain services such as prisons' stores (canteen) where prisoners find food, hygiene products, clothing...etc. On the other hand, the reduction is mainly the result of the offloading of part of the justice and prison costs onto the Palestinians and the international community: to the Palestinian Authority and its donors, and to NGOs, political parties, defendants and their families with the monetarization of the judiciary and the prison systems which have become relatively cost-effective for the Israeli state.

Indeed, from the 90's onwards, the Army started its managerial revolution with the implementation of neoliberal reforms such as outsourcing, downsizing, privatization and the introduction of values of competition, performance and good governance (Havkin 2017). These major changes in public governance were aimed at saving money, reframing the state's intervention and its responsibility. Main control devices were affected by these neoliberal reforms in addition to the military judiciary and the prison: 'border' checkpoints' management was privatized (Havkin 2017) and the main bulk of the administrative load of the Israeli Army

\footnotetext{
${ }^{27}$ See Daka 2009, 2011 ; Latte Abdallah 2011, 2012, 2015.
} 
Civil Administration of the West Bank was offloaded onto the Palestinian Authority (PA) through cooperation frames that have downsized its scope and payroll by 90 per cent whilst extending its grip on Palestinians (Berda 2017).

Similarly, part of detention costs was transferred to the Palestinian Authority which has become a de facto financial and administrative intermediary in the Israeli prison system (Latte Abdallah 2011, 2015, 2017). In this sense, we can consider that the Palestinian Authority, and its European and international funders, contribute to the functioning and profitability of Israeli military justice and prisons. With the resumption of mass incarcerations, the role of the Palestinian Ministry of Prisoners of War and ex-detainees and its financial investment increased (it became in 2014, the High commission for prisoners of war and former detainees under the umbrella of the PLO). To help families and strengthen its national role, the PA has provided legal assistance and granted a monthly sum for each Palestinian security inmate - whether from the OT, Jerusalem or from Israel - and for every Arab prisoner, irrespective of their political affiliation. The amount depends on the time spent in prison, family status and place of residence $^{28}$. The High Commission adds a sum intended for purchases at the prison shop. In August 2004, Shabas dramatically reduced the food and basic necessities provided to detainees (detergents, soap, basic clothing, shoes, etc.). Most collective and family donations have been banned. Multiple daily purchases at the prison shop, whose prices were increased by privatization, became necessary. Families send additional money to their relatives 'for the canteen' to cover their needs. In addition, the Ministry has been organizing and paying for the secondary education of Palestinian security inmates and, until 2011 when it was authorized, for the fees of any prisoner who aims to study in jail, i.e. at the Open university of Tel Aviv, which is a private institution which offers courses in Hebrew only. It was the only institution which the prisoners were allowed to register to, under specific conditions.

At the same time, the Shabas introduced a lucrative system of fines (around 400 shekels almost 100 euros) for any breach of the internal prison regulations in addition to the usual punishment (solitary confinement, prohibition of visits...etc.). These fines are deducted directly from the amount allocated for the canteen to each prisoner by the High Commission for prisoners. According to the 2010 budget of the Palestinian Ministry of Prisoners and ExDetainees, some 191 million shekels (around 47,4 million euros) are paid directly to the Israeli

\footnotetext{
${ }^{28}$ In 2011, they were revised upwards. The minimum is 1400 NIS - almost 350 euros - for a single of the Territories incarcerated less than 3 years. Saad Nimr, Chief of Staff of the Minister of Prisoners and ex-detainees Issa Qarake, Ramallah, 27/04/2011.
} 
Prison Service or spent annually for prisoners in detention ${ }^{29}$. Its total budget represented approximately 2.5 per cent of the PA's budget. The aid granted for the payment of fines (received in prison or constituting part of the sanctions at the trial) was NIS 1,1 million annually $(€ 273,000)$ and the support to lawyers' fees and expenses was about 9.6 million shekels $(2.4$ million euros) ${ }^{30}$.

Moreover, the PA imprisons some detainees previously held in Israeli penitentiaries which reduces the costs and responsibility for Shabas: since the split between Hamas and Fatah (2007), political prisoners whom are called 'Security Prisoners' have been detained in the Palestinian Authority prisons in the West Bank and in Hamas prisons in the Gaza Strip. In the West Bank, it targets different groups: 'dissidents' of the security forces or Fatah such as supporters of Mohamed Dahlan, members of Hamas and Islamic Djihad, some of the popular resistance activists, people held behind bars for their 'protection', i.e. to avoid incarceration inIsrael. The development of the Palestinian security forces has been linked to their ability to arrest and detain Hamas members, who are therefore less likely to be managed by the Israeli prison system ${ }^{31}$. The cooperation agreements between the PA and the United States, set up forthe training of the security services, responsible for the military prisons in the West Bank wherepolitical prisoners are held, have facilitated the detention of Hamas or Islamic Jihad prisoners. Security cooperation between the Israeli Army and the Palestinian Security Forces for the arrestof these militants has been pursued so far despite the strong protests against it.

In addition to the PA, other actors have become de facto involved in the functioning of military justice and political imprisonment. On top of its regular missions towards prisoners, the International Committee of the Red Cross (ICRC) transmits applications for entry permits into Israel for Palestinians living in the West Bank and the Gaza Strip wishing to visit their parents in detention; and organizes bus transportation of the families to jails. According to a Knesset report, in 2008 the ICRC monitored the visits of 192,000 people, which represented a cost of 4 million Swiss francs (about 3.6 million euros) ${ }^{32}$. Finally, Palestinian NGOs provide legal assistance during litigation proceedings: the main ones are Nadi al-asir (The club of the Prisoner

\footnotetext{
${ }^{29}$ Calculation done out of the figures of the of Report on the Expenditure of the Ministry Prisoners and ExDetainees for 2010 in shekels (Taqrir mudafu'at wazara shuun al-asra o al-muhararin l'am 2010 bilshiql-s).

${ }^{30}$ Report on the Expenditure of the Ministry of Prisoners and Ex-Detainees for 2010 in shekels, op. cit.

${ }^{31}$ In 2009, unofficial data from the International Committee of the Red Cross (ICRC) estimated that in total approximately 2000 people were being held in Palestinian prisons run by the PA in the West Bank and by Hamas in the Gaza Strip. And the number of security prisoners in Israël was concomitantly reduced of approximately 2000 people. Since then, the number of security detainees in the West Bank and Gaza has decreased significantly (between 50 to 100 hundred in each location) and has fluctuated according to the political situation in the West Bank and the state of relations between the governments of Ramallah and Gaza.

${ }^{32}$ Knesset, Report on security prisoners (in Hebrew), 2009, Knesset website.
} 
of War) founded in 1992 by a group of former detainees and now a semi-governmental organization $^{33}$ and Addameer in the West Bank and Jerusalem, the Palestinian Center for Human Rights and Mizan in the Gaza Strip, and the Yussef al-Sadiq association in Um al-Fahm which is taking care of Palestinians who are Israeli citizens. They also initiate appeals and petitions to Israeli courts and the Israeli Supreme Court in collaboration with Israeli NGOs.

\section{Monetarization of the judiciary and the prison business}

Over time, the interactions of military judges and prosecutors, Israeli and Palestinian officials, lawyers, defendants and their families have led to the emergence of a prison business. Lawyers in military courts, paid by Palestinian NGOs, the Palestinian High Commission for Prisoners, political parties or those working privately are key actors in the functioning of a military justice and prison system which have become monetarized. In the military court, the systematization of plea-bargaining contributes to the monetarization of the system. It entails an increased proximity between the lawyers and the military system through judges and prosecutors. Lisa Hajjar described the systematic use of plea-bargaining as a 'suq of deals' (2005) that results in a fragmentation of the legal practice (Hajjar, 2005) and individualization which have been further increased by the growing importance of money in the proceedings and overall military judiciary system.

Lawyers, who are mostly 48 Palestinians and Jerusalemites (few others are West bankers or Jewish Israelis) do not believe in the possibility of a consistent defense in this context. Some stop pleading in military courts after a few years, demoralized by a practice that they see as a form of legal validation of the occupation. Others fight with conviction and try to get the best for their clients in such a context. A minority, finally, use the system for their profit to make money. To obtain advantageous plea-bargains, one must have, at least visibly, good relations with the judges. It might entail relations of cronyism, various forms of 'friendship' and socialization more or less governed by professional interests. As Hava Halevi of Court Watch noted, judges have an interest in favoring certain lawyers: 'For judges it is interesting to arrange advantageous plea-bargains with the lawyers they like. It creates an easy and useful connections between the Palestinians and the army ${ }^{34}$. To get good deals, lawyers need to have a very precise knowledge of the way judges and prosecutors work. This proximity might result in a performed complicity between judges, prosecutors, translators, soldiers present in the courtroom and lawyers, made of news exchanges, brief discussions on daily life which contrasts with the way

\footnotetext{
${ }^{33}$ It is mostly funded by the High Commission for the prisoners of war and ex-detainees.

${ }^{34}$ Interview, Jerusalem, 06/12/2014.
} 
in which the defendant and his family are kept at a distance, or even patronized. The circulation of money in cash between clients and lawyers, as well as the sociability and information exchanged between lawyers and military prosecutors and judges suggest the existence of forms of corruption. At the end of a trial, I was indeed surprised to hear the lawyer asking on a low voice to his clients' family, accused of arms and Viagra trafficking, how much they were willing to pay to have them back home soon and to bring him the amount in cash to show it to the judge. This prison business is based on an assessment of what clients can pay according to their social status and what they are willing to do to prevent their loved one from spending too much time in prison: "How much can you pay?" is a question some lawyers ask to know how to settle the cases. It might entail tensions and pressure between relatives when mothers ask their husbands or sons to find the money needed to get a son, daughter, brother or father out. Families want them to be released as soon as possible. They wish to hire the best lawyers, who are usually the ones who are known to obtain the most advantageous safqa-s. Some of them charge high fees for their good reputation and ability to negotiate with the system. Lawyers are both overinvested by family expectations and strongly criticized because of their limited leeway in the context of military justice. This overinvestment translates into a form of faith in the money paid to the lawyer to find a solution. Many lawyers work at the same time for the legal department of the High Commission for Prisoners or for NGOs providing support to prisoners (Nadi al-Asir, Addameer) and privately. These NGOs cover the main bulk of lawyers' fees. Some lawyers commit to obtain more favorable safqa-s if they plead on their own behalf with higher fees. And it is not uncommon to see families preferring, for the same reasons, to hire a private lawyerwho will indeed be able to spend more time on the file, though in the end, the sentences obtainedare rarely more lenient. Paying a lawyer dearly reinforces the feeling to do its utmost for the child or loved one.

For a decade, the systematization of fines and the subsequent increase in their amount as part of the sentences or in lieu of prison sentences show the enhanced weight of money. According to a report by the Israeli NGO Yesh Din (2007), the total fines paid in court proceedings increased from NIS 7051305 (around $€ 1.7$ million) in 2002 to almost 12 million (€ 2.9 million) in 2006. Since then, this trend has grown steadily: in 2017, according to figures of the Military Court published by Addameer, it rose to 20 million shekels (almost 5 million euros) ${ }^{35}$. The Palestinian Authority first limited its support to 4,000 shekels (around $€ 990$ ) per prisoner to pay court fines and stopped it completely in 2014 to avoid covering the cost of military justice.

\footnotetext{
${ }^{35} \mathrm{http}: / /$ www.addameer.org/publications/military-courts-occupied-palestinian-territory.
} 
The exchange between months of imprisonment and fines for offenses that entail short prison terms has become routine: nowadays one month in prison equals approximately 1,000 shekels $(€ 248)$. As lawyer Abeer Bakr noted: 'This is the rate ${ }^{36}$. Fines generally range from 1,000 to 20,000 shekels (almost 5000 euros). Moreover, to each prison sentence is now added a fine penalty whilst this is not always the case in Israeli Civil Courts: 'In Israel, when you get a prison term, you are rarely fined, contrary to what is customary in military court. The safqa-s are a way to try to buy less months, and in those cases, the fines increase' ${ }^{37}$.

Besides, since the 2000s, the progressive formation of an in-between border space in the West Bank improved the system's cost-effectiveness and efficiency. Indeed, the expansion of the jurisdiction of military courts to civil offenses and specifically to all traffic offenses committed in zone $\mathrm{C}$ but also in zone $\mathrm{B}$ proved to be very lucrative as the main sanction for traffic offenses, which are both minor and frequent, is the payment of fines. These fines that were previously collected by the Palestinian Authority are steadily increasing with the bulk of traffic offenses that the Israeli Military courts are trying. The Israeli lawyer Gaby Laski and Hava Halevi from Court Watch share the same findings. The latter noted: 'It is the Palestinians themselves who finance the courts. The most important thing in this system is money, and poor people cannot fight $^{\prime 38}$.

In addition, the payment of bails is customary to be released pending a judgment or in the case of simple arrests followed by a court appearance. This procedure is quite lucrative. It is all the more so as arrests have multiplied in recent years notably of minors and young Palestinians from the West Bank and even more so from Jerusalem. This significant rise in arrests is not always visible in the Israel Prison Service statistics: indeed, many are released after paying a bail though they are often re-arrested shortly afterwards and several times a year. The amounts of bails vary between 1,000 ( $€ 248$ ) and 20,000 shekels (almost 5000 euros) or even 25,000 shekels (€ 6200). This system is particularly profitable since despite the legal provision, this money is almost never recovered. The repayment of bails is not automatic and the bureaucratic procedure is almost impossible to complete, especially for West Bankers. Given the scale of the phenomenon, the office of the lawyer Gaby Lasky, the NGOs Court Watch and Hamoked have recently undertaken steps to guarantee the return of these amounts to people: 'These are

\footnotetext{
${ }^{36}$ Interview, Acre, 30/10/2014.

${ }^{37}$ Gaby Lasky, Lawyer, Interview, Tel Aviv, 22/07/2012.

${ }^{38}$ Hava Halevi, Interview, Jerusalem, 06/12/2014.
} 
huge sums that are blocked over there. Everything is done to prevent people from clawing their money back $^{39}$.

\section{Conclusion}

The rules and fonctionning of the judiciary have created a Prison Web over the Palestinian territories, i.e., a reality of massive arrests and imprisonment and a virtuality, a larger possibility of detaining, that is to say a suspended detention likely to affect almost everyone. It pervades the whole daily, social and political life of Palestinians from the West Bank and East Jerusalem and, to a much lesser extent since the 2005 disengagement, of Gazans. The Prison Web, military justice and the prison are indeed key control devices in a discontinuous territory without state line borders. Together with the permit system, they are shaping a dematerialized bordering system which has gradually been implemented in the West Bank since the second Intifada. Through prison neoliberal reforms, the monetarization of military justice and expansion of its action scope, costs of the Prison Web were reduced and offloaded onto Palestinians and international actors. It has turned sustainable and contributed to redeploy the occupation through a specific control and bordering system. Meanwhile, the settlers have also become key actors of bordering in lieu of the State. Indeed, the majority of military judges are settlers and they acquired great power within the civil administration in charge of delivering permits (Berda, $2017: 108)$.

This Prison Web is anchored on the expanding role of the intelligences services during arrests, interrogations, litigation, detention and after the release of the defendants. They work on data collection and biosocial profiling and target not only the individual but his relatives and various networks. Hence, part of the bordering processes have been transfered onto the intelligence services. Thus, bordering has become both networked and highly individualized. Mobile, everywhere and at the same time invisible, these networked and individualized borders are both endless and suspended. They are shaping an in-between border space in the West Bank which is characterized by indetermination, uncertainty, disorientation and violence. Such endless borders have a major impact on creating deep distrust among Palestinian society, on hampering collective and political mobilization and expanding the grip of colonization over bodies (Latte Abdallah 2014, 2015 ; Berda 2017) whilst shaping specific subjectivities, ever-emerging ways to cope and militant, social, citizen and artistic resistances.

\footnotetext{
${ }^{39}$ Gaby Lasky, interview, Tel Aviv, 22/07/2012.
} 


\section{Bibliography}

Addameer (2013) Fragile, Courageous Voices, Fragile Freedoms. Israel's Arrest and Detention of Palestinian Human Rights Defenders against the Annexation Wall (Ramallah: Addameer).

Abunimah, A. (2014) The Battle for Justice in Palestine (Chicago: Haymarker Books).

Abu Zahra, N., Kay, A. (2013) Unfree in Palestine, Registration, Documentation and Movement Restriction (London: Pluto Press).

Agamben, G. (1997) Homo Sacer, le pouvoir souverain et la vie nue, Paris, Seuil.

Ben Naftali, O., Gross A. and Michaeli, K. (2009) The Illegality of the Occupation Regime: The Fabric of Law in the Occupied Palestinian Territory, in : A. Ophir, M. Givoni \& S. Hanafi (Eds) The Power of Inclusive Exclusion. Anatomy of Israeli Rule in the Occupied Palestinian Territories (New York : Zone Books).

Berda, Y. (2017) Living Emergency. Israel's Permit Regime in the Occupied West Bank (Stanford: Stanford University Press).

Bontemps, V. (2017) 'Tu dois prendre le risque, tu n'as pas le choix'. Entre précarisation et décision individuelle, récits d'ouvriers palestiniens travaillant en Israël, in: S. Latte Abdallah \& C. Parizot (Eds) Israël-Palestine. L'illusion de la separation (Aix-en-Provence: Presses Universitaires de Provence).

Bigo, D. (2010) Frontières, territoire, sécurité, souveraineté, Ceriscope, 30/11, Available at http://spire.sciencespo.fr/hdl:/2441/eu4vqp9ompqllr09i45ao4c3h/resources/frontieresterritoire-securite-souverainete.pdf (accessed 12 September 2014).

Bigo, D. \& Guild, E. (Eds) (2005) Controlling Frontiers: Free Movement into and within Europe (London: Ashgate).

Bornstein, A. (2008) Military Occupation as Carceral Society. Prison, Checkpoints and Walls in the Israeli-Palestinian Struggle, Social Analysis, Vol. 52, Issue 2, Summer, p. 106-30.

Bornstein, A. (2010) Palestinian Prison Ontologies, Dialect Anthropol, 34, p. 459-72.

Braverman, I. (2011) Civilized Borders: A Study of Israel's New Crossing Administration, Antipode, 43 (2), p. 264-95.

B'Tselem, http://www.btselem.org/statistics (accessed 27 April 2018).

Daka, W. (2009) Consciousness Molded or the Re-Identification of Torture (Israel: Jalbu'a Prison). Most of this testimony has subsequently been published in A. Bakr \& A. Matar (Eds.) (2011) Threat. Palestinian Political Prisoners in Israel (London: Pluto Press), p. 234-253. 
Dayan, H. (2009) Regimes of Separation: Israel/Palestine and the Shadow of Apartheid, in: A. Ophir \& M. Givoni \& S. Hanafi (Eds) The Power of Inclusive Exclusion: Anatomy of Israeli Rule in the Occupied Palestinian Territories (New York: Zone Books).

Derek, G. (2004) The Colonial Present: Afghanistan, Palestine, Iraq (Malden: Blackwell).

Hajjar, L. (2005) Courting Conflict. The Israeli Military Court System in the West Bank and Gaza (California: University of California Press).

Halevi, H., Shlonsky, H. \& Machsom Watch (2008) Guilty. Membership and Activity in Unlawful Associations. Military Courts 2008 (Jerusalem : MachsomWatch).

Halper, J. (2000), Matrix of control, Middle East Report 216, Fall.

Havkin, S. (2015) Outsourcing the Checkpoints: When Military Occupation Encounters Neoliberalism, in: S. Latte Abdallah \& C. Parizot (Eds), Israelis and Palestinians in the Shadows of the Wall. Spaces of Separation and Occupation (Surrey/Burlington : Ashgate).

Human Rights Watch (1991) Annual Report.

Israel Prison Service, Ordonnance 04.05.00, updated version 18/3/2014 (in Hebrew).

Khalili, L. (2013) Time in the Shadows. Confinement in Counterinsurgencies (Stanford: Stanford University Press).

Knesset (2009) Report on Security detainees (In Hebrew), Available at www.knesset.gov.il (accessed 15 October 2014).

Latte Abdallah, S. (2011) Déni de frontières. Toile carcérale et management des prisonniers politiques palestiniens après Oslo (1993-2010), in S. Latte Abdallah \& C. Parizot (Eds) $\dot{A}$ l'ombre du Mur. Israéliens et Palestiniens entre occupation et séparation (Arles : Actes Sud). Latte Abdallah, S. (2012) Les Palestiniens dans la toile carcérale, Le Monde Diplomatique (Paris), June.

Latte Abdallah, S. (2013) Des féminités mobilisées et incarcérées en Palestine, Critique Internationale, Issue 60, p. 53-69.

Latte Abdallah, S. (2014) Entre dedans et dehors : vécus parentaux des détenus politiques palestiniens en Israël, Champ pénal/Penal Field, Special Issue (XI) Parentalités enfermées/Detained Parenthood, C. Cardi \& S. Latte Abdallah (Eds), Available at www.champpenal.revues.org.

Latte Abdallah, S. (2015) Denial of Borders : The Prison Web and the Management of Palestinian Political Prisoners after the Oslo Accords (1993-2013), in S. Latte Abdallah \& C. Parizot (Eds) Israelis and Palestinians in the Shadows of the Wall. Spaces of Separation and Occupation (Surrey/Burlington: Ashgate). 
Latte Abdallah, S. (2017) L'incarcération politique des Palestiniens comme paradigme du régime de mobilité, in S. Latte Abdallah \& C. Parizot (Eds) Israël-Palestine. L'illusion de la separation (Aix-en-Provence: Presses Universitaires de Provence).

Latte Abdallah, S. \& Parizot, C. (Eds) (2017) Israël-Palestine. L'illusion de la separation (Aixen-Provence: Presses Universitaires de Provence).

Machsom Watch (2007) Invisible Prisoners. Palestinians Blacklisted by the General Security Services (Jerusalem: Machsom Watch).

Military Court Units (2007) Annual Report on Activity (in Hebrew) (Israel: State of Israel, Ministry of Defense).

Ministry of Prisoners and ex-detainees (2010) Report on the Expenditure of the Ministry Prisoners and Ex-Detainees for 2010 in shekels (in Arabic) (Taqrir mudafu'at wazara shuun al-asra o al-muhararin l'am 2010 bilshiql-s) (Ramallah : Ministry of Prisoners and exdetainees).

Nashif, I. (2008) Palestinian Political prisoners. Identity and Community (Oxon/New York: Routledge).

Natsheh, B. \& Parizot, C. (2011) From Chocolate Bars to Motor Cars: Separation and Goods Trafficking between Israel and the West Bank (2007-2010), in S. Latte Abdallah \& C. Parizot (Eds) Israelis and Palestinians in the Shadows of the Wall. Spaces of Separation and Occupation (Surrey/Burlington: Ashgate).

Parizot, C. (2017) Une économie du contrôle 'non documentée'. Travailleurs, passeurs et autorités dans le sur israélo-palestinien (2004-2010), in: S. Latte Abdallah \& C. Parizot (Eds) Israël-Palestine. L'illusion de la separation (Aix-en-Provence: Presses Universitaires de Provence).

Parsons, N. (2010) Israeli Biopolitics, Palestinian Policing. Order and Resistance in the Occupied Palestinian Territories, in Khalili L. \& Schwedler J. (Eds) Policing and Prisons in the Middle East: Formations of Coercion (London: Hurst and Company).

Parsons, N. \& and Salter, M. (2008) Israeli Biopolitics : Closure, Territorialisation and Governmentality in the Occupied Palestinian Territories, Geopolitics, 13 :701-723.

Petti, A. (2008) Asymmetries, in Farquharson, A. (Ed) The Impossible Prison (Nottingham: Centre for Contemporary Art).

Popescu, G. (2012) Bordering and Ordering the Twenty-first Century. Understanding Borders (Plymouth: Rowman and Littlefield Publishers).

Tsemel, L. (1985) Double Standard Justice in Israel: The Case of the Jewish Terror Organization, Palestine Yearbook of International Law 2, p. 37-68. 
Wacquant, L. (2009) Punishing the poor. The Neoliberal Government of Social Insecurity (Durham/London: Duke University Press).

Weizman, E. (2007) Hollow Land. Israel's Architecture of Occupation (London/New York: Verso).

Yesh Din (2007) Backyard Proceedings. The Implementation of Due Process Rights in the Military Courts in the Occupied Territories (Tel Aviv: Yesh Din). 